\section{Боби Бадаревски}

\section{Sammy Smooha and Priit Järve (eds), The Fate of Ethnic Democracy in Post Communist Europe, \\ Budapest: Open Society Institute, 2005.}

\section{Bobi Badarevski}

\section{Sammy Smooha and Priit Järve (eds), The Fate of Ethnic Democracy in Post Communist Europe,}

Budapest: Open Society Institute, 2005.

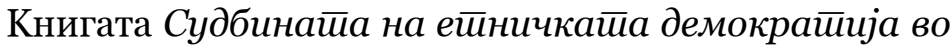
йоси-комунисиичкка Евройа, е збирка текстови приредена од Семи Смуха (Sammy Smooha) и Прит Јерве (Priit Järve), и претставува трет дел од серијата книги за етно-демократијата и малцинските прашања

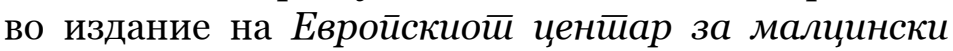
иррашања.

Основна нишка во книгата претставува воведниот текст на Семи Смуха кој го поставува концептот на етничка демократија како аналитичко средство во анализата на политичките збиднувања во посткомунистичка Европа. Појдовна точка во сите анализи поместени во зборникот е природата и карактерот на развојот на таканарачениот трет бран на демократизација кој ја зафати Западна Европа, но пред сѐ Централна и Источна Европа и земјите на поранешниот Советски сојуз. Гледиштата за вистинската состојба на теренот честопати се различни, па дури и дискрепантни и различно го третираат прашањето за демократизацијата на државите од таканаречениот посткомунистички блок.

Освен проблемите на демократизацијата, национализмот е исто така нешто што постоечката теоретска номенклатура не можеше правилно да го идентификува во контекстот на споменатите земји. Западните
Libri Fati i demokracisë etnike në Evropën postkomuniste është një përmbledhje tekstesh e përgaditur nga Semi Smuha (Sammy Smooha) dhe Prit Jerve (Priit Järve) dhe paraqet pjesën e tretë të serisë së librave për etnodemokracinë dhe çështjet e minoriteteve në botim të Qendrës evropiane për çështje të minoriteteve.

Nyjë themelore në libër paraqet teksti hyrës i Semi Smuhës, i cili e shtron konceptin e demokracisë etnike si mjet analitik në analizën e ngjarjeve politike në Evropën postkomuniste. Pikënisje në të gjitha analizat, që janë të vendosura në këtë përmbledhje, është natyra dhe karakteri i zhvillimit të të ashtuquajturës valë të tretë të demokracisë e cila e përfshiu Evropën perëndimore, por para së gjithash Evropën qendrore dhe lindore dhe vendet e ish Bashkimit Sovjetik. Pikëpamjet për gjendjen e vërtetë në terren shpeshherë janë të ndryshme e madje edhe diskrepante dhe në mënyrë të ndryshme e trajtojnë çështjen e demokratizimit të shteteve nga i ashtuquajturi bllok postkomunist.

Përveç problemeve të demokratizimit, nacionalizmi është poashtu diçka që nomenklatura ekzistuese teorike nuk mundej ta identifikojë drejt në kontekst të vendeve të përmendura. Demokracitë perëndimore ofruan një koncept 
демократии нудеа концепт на нација и национализам кој не можеше да се аплицира во анализите на случувањата во Источна Европа, а посебно на Балканот, каде што се водеа етнички војни. Меѓутоа, и тука проблемите не престануваат. Марксистичките и идеолошките матрици на социјалистичките земји развија сопствени концепти на народ, нација, етничка група кои, кога ќе се преведат на јазикот на западната теоретска мисла, ја губат својата смисла.

„Големото недоразбирање“ продолжува и во оваа книга, посебно во концепцијата на Смуха. Според

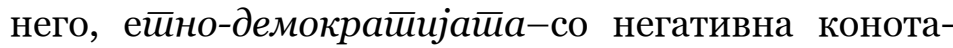
ција - претставува режим или политички систем кој ги обезбедува демократските и граѓанските права за сите, односно за сите граѓани во државата, меѓутоа, ја институционализира доминацијата на една етничка група. Практично, етно-демократијата се темели на два контрадикторни принципа: демократскиот принцип - права и слобода за сите, и етничкиот принцип - институции на еден етнос, а со тоа и доминација на една етничка група.

Да биде парадоксот уште поголем, токму на овој начин би можеле да ги опишеме сите современи западни демократии кои, иако се претставени како либерални демократии, и понатаму остануваат национални држави на доминантните народи во тие држави. Меѓутоа, дискурсот кој се формира околу посткомунистичките земји повлекува со себе и различни конотации, и тоа негативни, иако би можеле да се обложиме на еквивалентноста на концептите. Би можеле да се согласиме со намерата на уредниците и авторите за развивање на теоретска рамка со која ќе се разберат поновите феномени во политичката историја на Европа, но не по цена на теоретска ароганција и желба за атрактивност. të kombit dhe të nacionalizmit i cili nuk mund të aplikohej në analizat e ngjarjeve në Evropën lindore, e veçanërisht në Ballkan, ku u bënë luftëra etnike. Ndërkaq, edhe këtu problemet nuk pushojnë. Matricat marksiste dhe ideologjike të vendeve socialiste zhvilluan koncepte vetanake për popullin, kombin, grupin etnik, të cilat kur do të përkthehen në gjuhën e mendimit teorik perendimor, e humbin kuptimin e vet.

"Mosmarrëveshja e madhe" vazhdon edhe në këtë libër, veçanërisht koncepti i Smuhës. Sipas tij, etno-demokracia - me konotacion negativ - paraqet një regjim ose sistem politik i cili i siguron të drejtat demokratike dhe qytetare për të gjithë, përkatësisht për të gjithë qytetarët në shtet, ndërkaq e instutucionalizon dominimin e një grupi etnik. Praktikisht, etno-demokracia bazohet në dy parime kontradiktore: parimi demokratik - të drejta dhe liri për të gjithë dhe parimi etnik - institucionet e një etnosi, e me këtë edhe dominimi i një grupi etnik.

Që të jetë paradoksi edhe më i madh, pikërisht në këtë mënyrë do të kishim mundur t'i përshkruajmë të gjitha demokracitë perendimore të cilat edhe pse janë prezantuar si demokraci liberale edhe më tutje mbeten shtete nacionale të popujve dominantë në ato shtete. Ndërkaq diskursi i cili formohet rreth vendeve postkomuniste tërheq me vete edhe konotacione të ndryshme madje edhe negative, edhe pse do të kishim mundur të vemë bast për ekuivalencën e koncepteve. Do të kishim mundur të pajtohemi me qëllimin e redaktorëve dhe të autorëve për zhvillimin e kornizës teorike me të cilën do të merren vesh fenomenet më të reja në historinë politike të Evropës, por jo me çmimin e arrogancës teorike dhe të dëshirës për atraskion

Përkthim: Lindita Ahmeti 